\title{
Topical effects of autogenous, allogenous and xenogenous blood serum on the healing of alkali burns in the cornea of dogs
}

\section{Efeitos tópicos dos soros sangüíneos autógeno, alógeno e xenógeno, na cicatrização de queimaduras por álcali, em córneas de cães}

\author{
Adriana T. J. Brunelli, ${ }^{\star}$ Carla F. Campos, ${ }^{\star}$ Ivia C. Talieri, ${ }^{\star}$ Felipe F.A.M. Vicenti, ${ }^{\star}$ Julieta R.E. Moraes, ${ }^{\star \star}{ }^{*}$ José L. Laus ${ }^{\star \star \star}$
}

\begin{abstract}
The topical effects of autogenous, allogenous and xenogenous blood serum on wound healing of alkali corneal ulcers were determined in 52 dogs divided into four groups (GI, GII, GIII and GIV). The effects of autogenous serum were studied in GI animals, those of allogenous serum in GII, and those of xenogenous serum in GIII. GIV animals received $0.9 \%$ buffered saline solution also by instillation. Events such as blepharospasm, secretion, conjunctival hyperemia and chemosis, corneal edema, neovascularization and pigmentation were evaluated macroscopically and statistically. The inflammatory response and evolution of corneal wound healing were analyzed by light microscopy. No significant clinical or histopathological differences were observed between groups. Corneal perforations occurred in five GI animals at 4, 10,11, 16 and 18 days of treatment, and in three GII animals at 4, 6 and 7 days. In GIII, one animal presented corneal perforations at 7 days and in GIV, two animals presented perforations at 8 days and one animal at 9 days of treatment. In the absence of perforations, the epithelium was found to be reconstituted, on average, at 15 days of treatment. Comparison of the groups showed no significant differences between treatments.
\end{abstract}

Keywords: cornea, alkali, blood serum, dogs.

\section{Resumo}

Foram comparados os efeitos tópicos dos soros sangüíneos autógeno, alógeno e xenógeno, sobre a reparação cicatricial em úlceras de córnea por álcali, em 52 cães, distribuídos em quatro grupos (GI, GII, GIII e GIV). Nos animais do Gl, foram estudados os efeitos do soro sangüíneo autógeno. Nos do Gll, os do soro sangüíneo alógeno e nos do GIII, os do soro xenógeno. O GIV foi tratado com solução salina balanceada a 0,9\%, também por instilação. Foram avaliados macroscopicamente e por análise estatística, eventos como blefarospasmo, secreção, hiperemia, congestão e quemose conjuntivais; edema, neovascularização e pigmentação corneanos. À microscopia óptica, avaliou-se a resposta inflamatória e a evolução da reparação cicatricial das córneas. Os resultados mostraram que entre os grupos não houve diferenças clínicas estatisticamente significativas e à histopatologia, também não foram notadas diferenças. Houve perfurações corneanas no Gl, em 5 animais, aos $4,10,11,16$ e 18 dias de tratamento. No Gll, elas foram observadas em 3 cães aos 4,6 e 7 dias. No GIII, houve um caso aos 7 dias e, no GIV, elas ocorreram em 2 animais aos 8 dias e em 1 aos 9 dias de tratamento. Naqueles em que não houve perfurações, aos 15 dias de tratamento, em média, o epitélio já se encontrava refeito. Mediante comparação entre os grupos, pode-se admitir que não houve diferenças entre os tratamento empregados.

Palavras-chave: córnea, álcali, soro sangüíneo, cães.

\section{Introduction}

Ulcerative keratitis caused by chemical burns is one of the most severe keratopathies (BROWN, WASSERMANN and DUNN, 1969). Alkali burns are more common than acid burns due to the frequency of alkali substances in chemical household cleaning products and chemical construction material (WAGONER, 1997).
Among other substances, collagenase inhibitors are indicated for the treatment of alkali burns. Substances with anticollagenase action such as blood serum (BROWN, SHINOBU and WELLER, 1969; BERMAN et al, 1973; SLATTER, 1990) exert beneficial effects on alkali burns (PATERSON et al, 1994). a1-Antitrypsin and a2- macroglobulin are serum proteins exhibiting anticollagenase activity (BERMAN et al, 1973) and are able to control the evolution of ulcers (BERMAN

\footnotetext{
* Graduate Students, Ophthalmology Section, Veterinary College, São Paulo State University UNESP. E-mail: dribrunelli@hotmail.com

** Associate Professor, DVM, PhD., Pathology Department, Veterinary College, São Paulo State University, UNESP, Jaboticabal, SP, Brazil.

***. Professor, DVM, PhD., Ophthalmology Section, Veterinary College, São Paulo State University, UNESP- Via de Acesso Prof. Paulo Donato Castellane s/n $n^{\circ}$ - CEP: 14884-900 - Jaboticabal, SP. E.mail: jllaus@fcav.unesp.br
} 
and DOHLMAN, 1975). a1-Antitrypsin is found in the stromal extracellular matrix and Descemet membrane of cells, and in organic fluids including aqueous humor and tears (TWINING et al, 1994).

a2-Macroglobulin, due to its high molecular weight, is found in small amounts in normal corneas (BERMAN and DOHLMAN, 1975), including the epithelium, stroma and endothelium (PATERSON et al, 1994). Its concentration in the cornea is 40 times higher than in the lacrimal film and 8 times higher than in the aqueous humor (PATERSON et al, 1994).

Serum proteins diffuse through the blood vessels of the limbus (BERMAN et al, 1973; PATERSON et al, 1994) and other structures of the eye (PATERSON et al, 1994). The advantages of blood serum for the treatment of alkali burns are the absence of toxicity to the ocular surface, together with its anticollagenase effects (BERMAN and DOHLMAN, 1975), while disadvantages include the need for conservation, short validity (BROOKS, 1997), small intervals between instillations and the risk of contamination (WARD, 1998).

The aim of the present study was to compare the topical effects of autogenous, allogenous and xenogenous blood serum on the healing of alkali burns in the cornea of dogs.

\section{Material and methods}

Fifty-two adult mongrel dogs of both sexes were divided into four groups (GI-GIV). The topical effects of autogenous blood serum were studied in $\mathrm{Gl}$ (15 dogs), those of allogenous serum in GIl (13 dogs), and those of xenogenous serum in GIII (11 dogs). GIV (13 dogs) received $0.9 \%$ buffered saline (sterile physiological solution - Alcon do Brasil).

The study was conducted according to the bioethical guidelines for animal handling recommended by the Association for Research in Vision and Ophthalmology (ARVO).

\section{Blood serum}

Blood samples were collected every three days by puncture of the jugular vein. The serum obtained after centrifugation was maintained at $4^{\circ} \mathrm{C}$ in sterile flasks and was used within a maximum period of $72 \mathrm{~h}$ (BROOKS, 1997). The xenogenous serum was obtained from healthy adult horses.

\section{Ulcer}

For the produce of ulcers, the animals were pretreated with intramuscular acepromazine maleate (1\% Acepran $₫$ - Univet S.A. Ind. Veterinária) at the dose of $0.05 \mathrm{mg} / \mathrm{kg}$ body weight. After $10 \mathrm{~min}$, the animals received a combination of tiletamine chlorhydrate and zolazepam chlorhydrate (Zoletil® - Virbac do Brasil) at the dose of $0.01 \mathrm{mg} / \mathrm{kg}$ body weight by intravenous infusion. The corneas were then desensitized with eyedrops containing tetracaine, epinephrine chlorhydrate and boric acid (Colírio Anestésico® - Allergan-Lok). The ulcers were induced in only one eye (left eye) at locations corresponding to the 12:00 and 15:00 o'clock positions in the upper quadrant of the cornea, including the part of the bulbar limbus and conjunctiva, using a filter paper disk (quantitative filter paper, JP 42-quality, $9 \mathrm{~cm}$ ) $8 \mathrm{~cm}$ in diameter and soaked in $3 \mathrm{M}$ alkaline sodium hydroxide $(\mathrm{NaOH})$ solution for $1 \mathrm{~min}$. After removal of the disk, the area was submitted to superficial debridement with a dry and sterile swab and the eyes were washed with sterile $0.9 \%$ saline solution for $1 \mathrm{~min}$.

\section{Treatments}

Blood samples and saline solution were instilled as established above for each group $4 \mathrm{~h}$ after ulcer at $6 \mathrm{~h}$ intervals until the fluorescein test was clinically negative. In the case of perforations, the animals were replaced with others in order to obtain equivalent groups for light microscopy analysis. However, the cases of perforation were considered in the study for final comparison of the results between groups.

To minimize the discomfort produced by ciliary spasm, the animals received topical atropine (1\% Atropine Eyedrops $®$ Allergan-Lok) at 12-h intervals during the first three days and then every $24 \mathrm{~h}$ until the 7 th day of treatment. Immediately after ulcer induction, the animals were injected subcutaneously with a single dose of $1.1 \mathrm{mg} / \mathrm{kg}$ body weight flunixin meglumine (Banamine ${ }^{\circledR}$ - Schering-Plough Veterinária).

\section{Clinical evaluation}

Signs of blepharospasm, secretion, conjunctival hyperemia and chemosis, corneal edema, neovascularization and pigmentation were recorded every $24 \mathrm{~h}$ and the results were analyzed ( $1,3,10,30$ and 60 days after lesion) based on subjective qualitative and quantitative criteria.

\section{Histopathological evaluation by light microscopy}

Corneas were evaluated $1,3,10,30$ and 60 days after treatment. The samples were fixed in Bouin fixative solution and post-fixed in ethyl alcohol, cut into 5- $\mu \mathrm{m}$ thick sections, stained with hematoxylin-eosin (HE) and Masson's trichrome and analyzed by light microscopy.

\section{Statistical analysis}

The clinical signs were analyzed by the Kruskal-Wallis test, with the level of significance set at $5 \%$ ( $p £ 0.05)$. The Fisher exact test was used to compare corneal perforations between groups.

\section{Results}

\section{Clinical evaluation}

The clinical findings were similar for all groups. Blepharospasm and ocular secretion were discrete until the 10 th day of treatment. Conjunctival hyperemia and congestion ranged from moderate to intense during the initial and intermediate periods and then became discrete or were absent at 60 days of treatment.

Moderate chemosis was observed until the 10th day in all groups and disappeared thereafter.

Corneal edema ranged from moderate to intense in all groups during the initial periods, with a tendency towards regression from the 30th day on, and was discrete at 60 days.

Vascular neoformation was evident in all groups. From the 10th day on, it was found to be discrete to moderate until the 30 th day. At 60 days, vascular neoformation ranged from 
discrete to absent. Discrete corneal pigmentation was observed 30 days after treatment in all groups.

The fluorescein test was negative, on average, 15 days after treatment for all groups. Corneal perforations were observed in all groups, with five animals being affected in GI at 4, 10, 11, 16 and 18 days of treatment and three in GII at 4, 6 and 7 days, while in GIII, only one case was observed at 7 days. In GIV, two animals presented perforations at 8 days and one at 9 days.

Adhesion of the conjunctiva to the lesioned cornea (conjunctivalization) occurred during the late periods in all groups. Figures 1, 2, 3 and 4 show the evolution of wound healing during the respective periods.

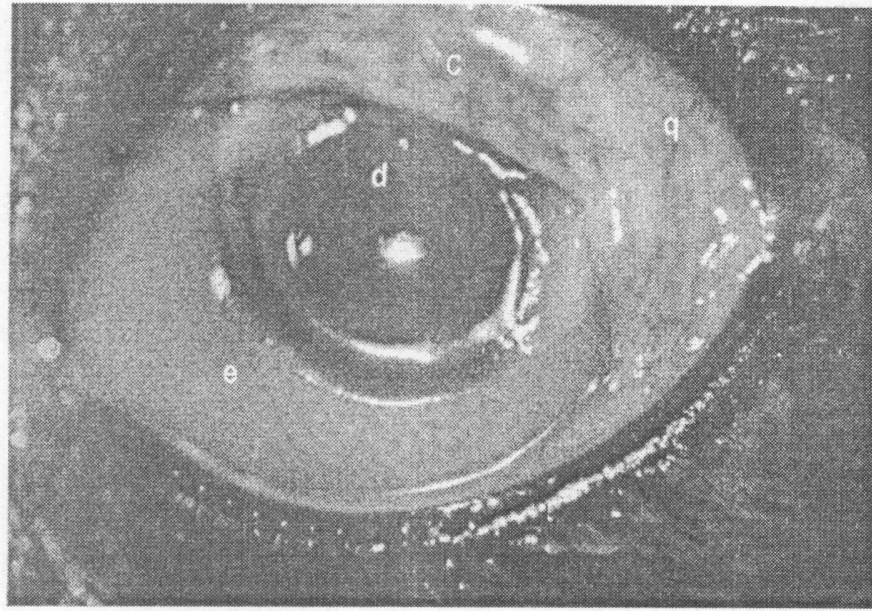

Figure 1: Photographic image of a dog eye at 3 days of treatment with autogenous blood serum. Marked conjunctival congestion (c), moderate chemosis (q), marked corneal edema (e) and an exposed Descemet membrane (d) can be observed.

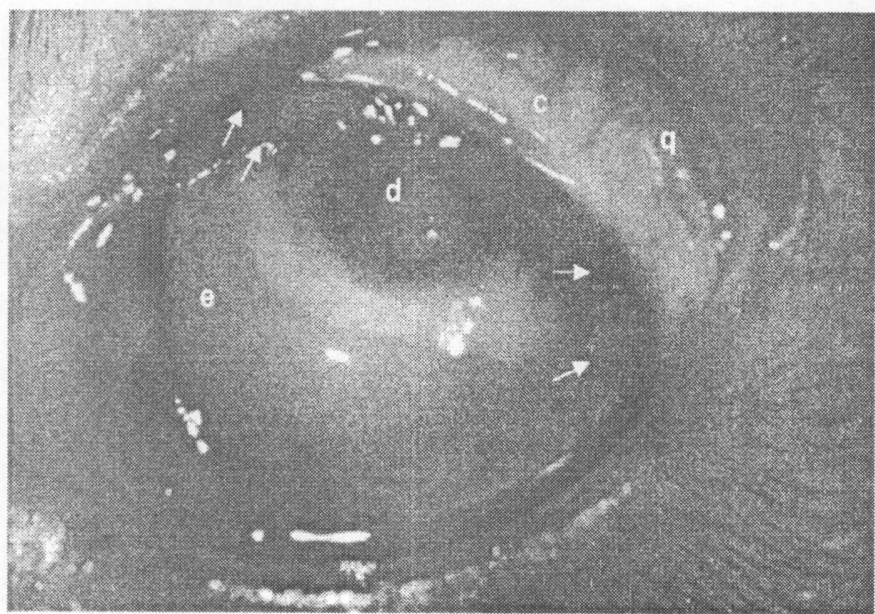

Figure 2: Photographic image of a dog eye at 10 days of treatment with autogenous blood serum. Marked conjunctival congestion (c), discrete chemosis (q), moderate corneal edema (e), moderate vascular neoformation (?) and an exposed Descemet membrane (d) can be observed.

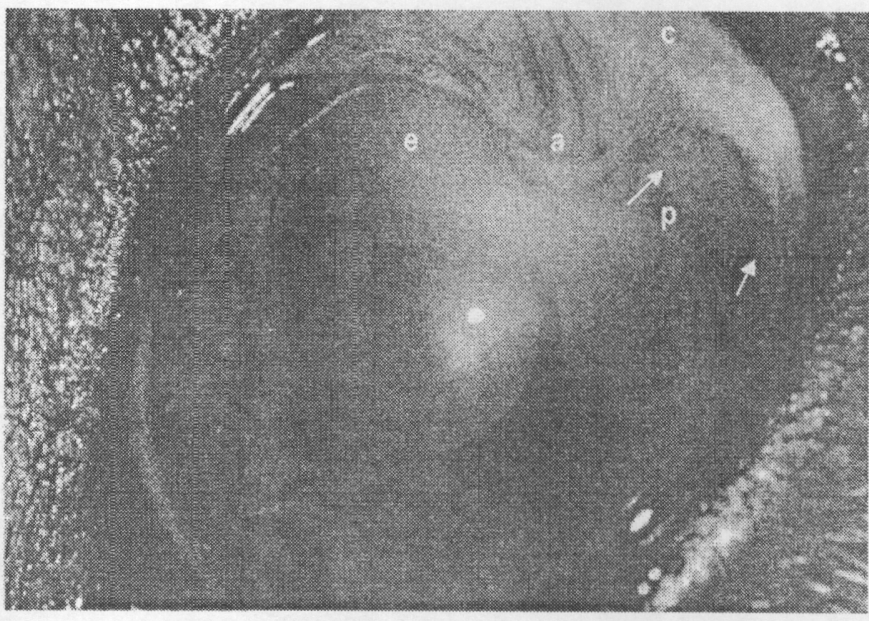

Figure 3: Photographic image of a dog eye at 30 days of treatment with xenogenous blood serum. Conjunctival congestion (c), ghost vessels (?) discrete corneal edema (e) and conjunctivalization (a) can be observed.

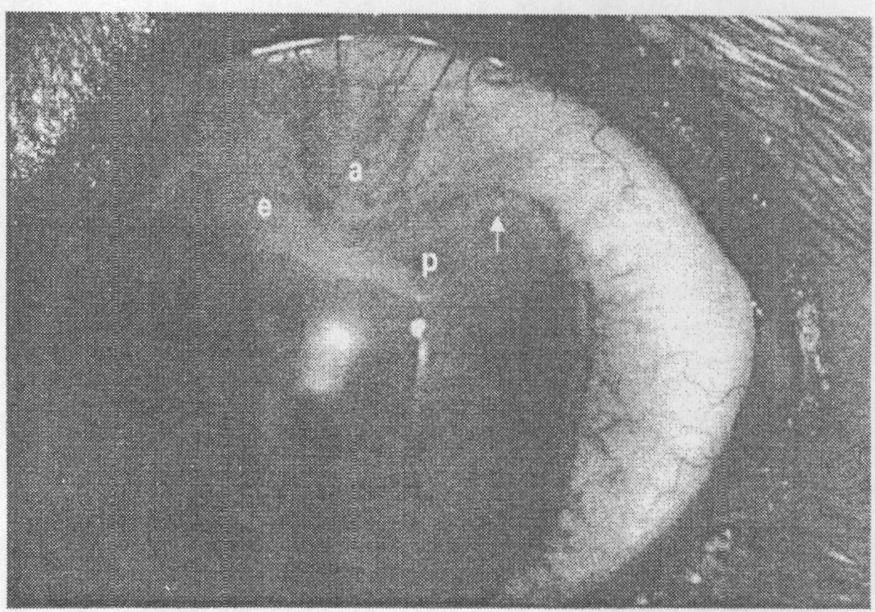

Figure 4: Photographic image of a dog eye at 60 days of treatment with xenogenous blood serum. Ghost vessels (?), discrete corneal edema (e), conjunctivalization (a) and discrete pigmentation ( $p$ ) can be observed.

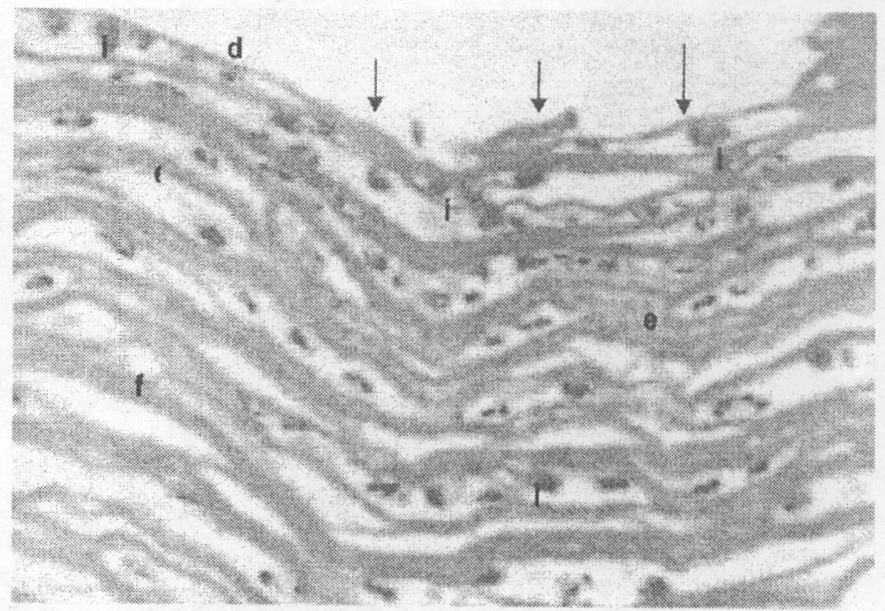

Figure 5: Photomicrograph of dog cornea at 3 days of treatment with allogenous blood serum. Note the absence of epithelium (d), tissue retraction (?), edema with dissociated collagen fibers (e), inflammatory cells (i) and the absence of fibrocytes (f) (HE, 40X). 


\section{Histopathological evaluation by light microscopy}

The findings were similar for all groups. The epithelium surrounding the lesioned corneal areas was absent until the 10th day, except for one GIII animal and one GIV animal in which the epithelium, although present at 10 days of treatment, showed important alterations such as subepithelial vacuoles devoid of cell debris. At 30 and 60 days, the epithelium was found to be regenerated, showing areas of hyperplasia and hypertrophy (figure 6,7 and 8).

The stroma edema was marked up to the 10th day and discrete during the late periods. The moderate polymorphonuclear leukocyte infiltration was observed by the 1st day and was intense from the 3rd day on (figure 5). Intense mononuclear inflammatory cell infiltration was observed after 10 days and was found to be discrete during the late periods. Newly formed

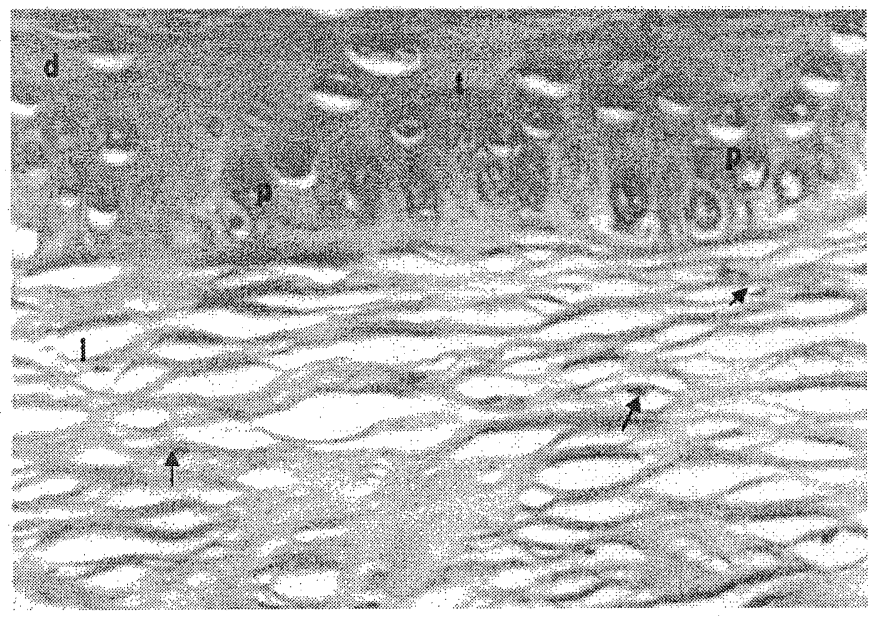

Figure 6: Photomicrograph of dog cornea at 30 days of treatment with autogenous blood serum. Note the regenerated epithelium (d) with areas of hyperplasia $(p)$ and hypertrophy $(t)$, lamellar organization (I) and the fibrocyte nucleus (?) (HE, 40X).

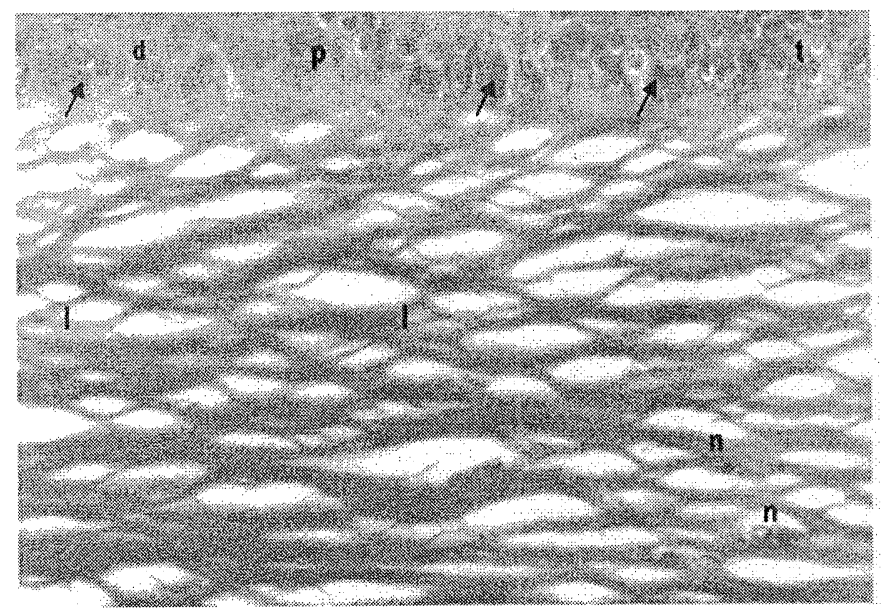

Figure 7: Photomicrograph of dog cornea at 60 days of treatment with xenogenous blood serum. Note the regenerated epithelium (d) with areas of hyperplasia $(p)$ and hypertrophy $(t)$, lamellar organization (l), discrete neovascularization $(n)$ and intraepithelial melanin pigmentation (?) (HE, 20X).

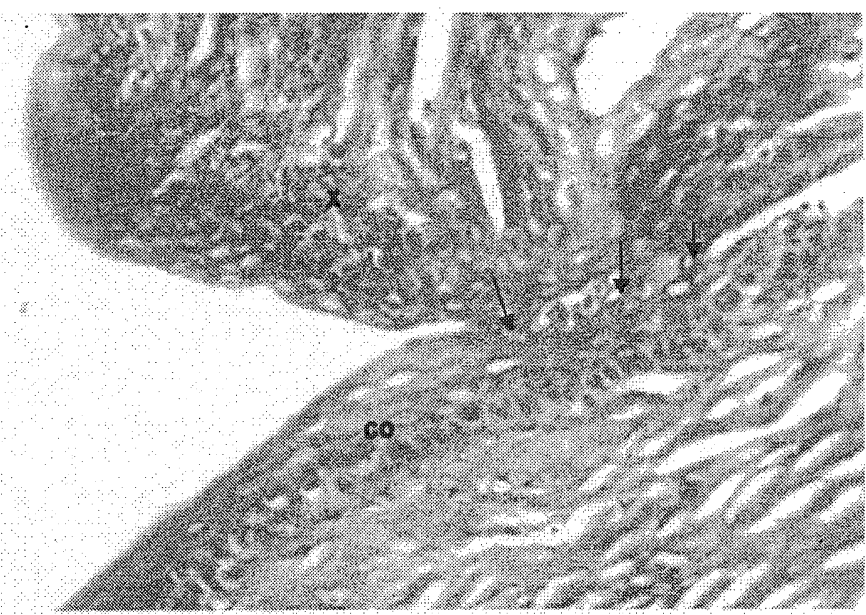

Figure 8: Photomicrograph of dog cornea at 60 days of treatment with xenogenous blood serum. Invasion of the conjunctiva $(x)$ above the cornea (co) in the lesion area (conjunctivalization) (?) can be observed (HE, 20X).

vessels were observed by the 3rd day of treatment and became discrete at 60 days. Discrete pigmentation of the epithelium and anterior stroma was observed by the 30th day of treatment.

The endothelium was found to be acellular up to the 10th day, filled with a fine and homogenous layer of eosinophils. Cell debris and inflammatory cells were observed inside the anterior chamber throughout the observation period, mainly in the control group.

\section{Statistical analysis}

No significant clinical differences were observed between groups. Analysis by the Fisher exact test showed that the observed perforations occurred independently of the type of treatment.

\section{Discussion}

Although alkali burns of the cornea are less common in dogs than in men (WHITLEY and GILGER, 1998), we decided to investigate these lesions since they represent a critical model for the study of anticollagenase substances and also because the design of the study would permit us to add to the little information available for dogs. It is generally accepted that alkali burns represent a great challenge to ophthalmologists (WHITLEY and GILGER, 1998), thus justifying the study of these lesions.

Different blood serum samples were compared in the present study. a1-Antitrypsin found in serum has also been isolated from human corneas, where it acts on polymorphonuclear leukocytes (TWINING et al, 1994). a2-Macroglobulin present in human serum has been used for the treatment of alkali burns, with good results (BERMAN and DOHLMAN, 1975). As expected, no toxic effects of serum on the ocular surface were observed in the present study (BERMAN and DOHLMAN, 1975). The beneficial action of this substance on corneal lesions has been emphasized in men and rabbits (BERMAN and DOHLMAN, 1975; PATERSON et al, 1994; DUA and AZUARABLANCO, 1999), as well as in dogs (WARD, 1998). 
Although instillations at 1 to $4 \mathrm{~h}$ intervals have been recommended (WARD, 1998; DUA and AZUARA-BLANCO, 1999), we evaluated intervals of $6 \mathrm{~h}$ to determine the effects of longer periods which would minimize the inconvenience of frequent administrations often impracticable due to the lack of time of the owners. With respect to the instillation period, serum was employed until corneal reepithelization was achieved (DUA and AZUARA-BLANCO, 1999). It is known that once it has healed, the epithelium no longer produces collagenase (BROWN, SHINOBU and WELLER, 1969).

Blepharospasm, epiphora and secretion are clinical signs of ulcerative keratitis (SLATTER, 1990). In the present study, these symptoms were observed in a discrete form during the initial treatment periods and disappeared during the late phase. Conjunctival hyperemia and chemosis which are due to the direct action of alkali were moderate to intense during the initial periods, as also reported in the literature (MATSUDA and SMELSER, 1973).

Edema and corneal opacification occurred due to stromal fiber derangement (WARING, 1984; WHITLEY and GILGER, 1998). On the first day, edema was not solely restricted to the lesioned areas, as also demonstrated previously (MATSUDA and SMELSER, 1973), while it was discrete during the late periods.

Newly formed blood vessels play an important role in the maintenance of the integrity of corneal structures in chemical burns (BROWN, WASSERMANN and DUNN, 1969). In the absence of neovascularization, perforations are frequently observed due to the condition of acellularity caused by the lack of blood vessels (BROWN, WASSERMANN and DUNN, 1969). A compromised limbus results in impaired vessel neogenesis, and the prognosis becomes unfavorable (BROWN, WASSERMANN and DUNN, 1969). In the present study, newly formed vessels occurred as early as by the 3rd treatment day, in contrast to the findings of other authors (BROWN, WASSERMANN and DUNN, 1969) who observed new vessels only at the end of the third week after the burn. In the present study, newly formed vessels arose from the limbus adjacent to the lesion in the direction of the lesioned area and were significant from the 10th day on, with a tendency towards regression during the late periods.

Invasion of the cornea by the conjunctiva was noted in all animals, with this phenomenon, which results from the destruction of stem cells, being observed by the 30th day. $A$ deficient limbus or loss of stem cells predisposes to the growth of conjunctival epithelium on the corneal surface (conjunctivalization) and may also produce chronic inflammation, ulceration, and melting and perforation of the cornea (DUA and AZUARA-BLANCO, 1999; DUA and AZUARABLANCO, 2000).

Stromal lesions are characterized by the total loss of keratocytes (GNÄDINGER et al, 1969; BURNS et al, 1990). The only cells found in the cornea and sclera after 10 days were polymorphonuclear neutrophils and mononuclear cells (PFISTER, FRIEND and DOHLMAN, 1971). At 30 days, the stroma showed moderate regeneration and keratocytes were present.

Retracted collagen fibers were commonly observed until the 10th day. This phenomenon is known to occur due to fiber hydration which results in the subsequent thickening and shortening of fibers (WAGONER, 1997). After 30 days, the collagen fibers became regular and organized, a fact also observed in the literature (FINI, GIRARD and MATSUBARA, $1992)$, leading to the gradual restoration of transparency close to the lesioned areas. At 60 days, collagen fibers showed partial lamellar organization.

The inflammatory cell component, initially characterized by polymorphonuclear cells, was found to be moderate to intense as early as on the first day, in agreement with the literature (GNÄDINGER et al, 1969), and was intense mainly at the lesion site and near the opposite bulbar conjunctiva by the 3rd day. Inflammatory cells were still being observed during the late periods due to the presence of vascularization (WARING, 1984). Polymorphonuclear neutrophils were predominant in the corneas with perforations (PFISTER and HADDOX, 1996). It is known that polymorphonuclear cells may contribute to the aggravation and, in some cases, to the perforation of ulcers (PFISTER and HADDOX, 1996).

Studies have reported the occurrence of corneal perforation secondary to the action of alkaline substances (BROWN, WASSERMANN and DUNN, 1969; BURNS et al, 1990). In rabbits, neovascularization has been found to be delayed when the limbus is involved, resulting in a high rate of perforations (BROWN, SHINOBU and WELLER, 1969). These perforations can be observed in up to $90 \%$ of cases when the limbus is destroyed and in $28 \%$ when the limbus is preserved (BROWN, WASSERMANN and DUNN, 1969). In the present study, the limbus was destroyed and in $23 \%$ of the corneas developed perforations between the 2nd and 3rd week.

In conclusion, the present results did not show differences between autogenous, allogenous and xenogenous blood serum and buffered saline solution used for the treatment of corneal ulcers by $3 \mathrm{M}$ sodium hydroxide.

\section{Acknowledgments}

Research supported by Fundação de Amparo à Pesquisa do Estado de São Paulo - FAPESP (Process No 98/03153-0 and 98/ 12803-9).

\section{References}

BERMAN, M. B. et al. Corneal ulceration and the serum antiproteasesI.- a'antitrypsin. Invest. Ophthalmol. Vis. Sci., v. 12, p. 759- 770, 1973. BERMAN, M. B.; DOHLMAN, C. Collagenase inhibitors. Arch. Ophthalmol., 1975, v. 35, p. 95-108, 1975.
BROOKS, D. E. (UNIVERSITY OF Florida). Pessoal comunication, 1997. BROWN, S. I.; WASSERMANN, H. E.; DUNN, M. W. Alkali burns of the cornea. Arch. Ophthalmol., v. 82, p. 91-94, 1969.

BROWN, S. I.; SHINOBU, A.; WELLER, C. A. Prevention of the ulcers of the alkali-burned cornea. Arch. Ophthalmol., v. 82, p. 95-97, 1969. 
BURNS, F. R. et al. Inhibition of alkali-induced corneal ulceration and perforation by a thiol peptide. Invest. Ophthalmol. Vis. Sci., v. 31, p. 107-114, 1990

DUA, H. S.; AZUARA-BLANCO, A. Allo-limbal transplantation in patients with limbal stem cell deficiency. Br. J. Ophthalmol., v. 83, p. 414-419, 1999.

DUA, H. S.; AZUARA-BLANCO, A. Autologous limbal transplantation in patients unilateral corneal stem cell deficiency. Br. J. Ophthalmol., v. 84, p. 273-2780, 2000.

FINI, M. E.; GIRARD, M. T.; MATSUBARA, M. Collagenolytic/ gelatinolytic enzymes in corneal wound healing. Acta Ophthalmol.,v. 70, p. 26-33, 1992.

GNÄDINGER, M. C. et al. The role of collagenase in the alkali-burned cornea. Am. J Ophthalmolol., v. 68, p. 478-483, 1969.

MATSUDA, H.; SMELSER, G. K. Epithelium and stroma in alkali- burned corneas. Arch. Ophthalmol., v. 89, p. 396-401, 1973.

PATERSON, C. A. et al. Recombinant tissue inhibitor of metalloproteinases type 1 suppresses alkali-burn-induced corneal ulceration in rabbits. Invest. Ophthalmol. Vis. Sci.; v. 35, p. 677-684, 1994.

PFISTER, R. R.; FRIEND, J.; DOHLMAN, C.H. The anterior segments of rabbits after alkali burns. Arch. Ophthalmol.; v. 86, p. 189-193, 1971.
PFISTER, R. R.; HADDOX, J. L. Aneutrophil chenoattractants is released from cellular and extracellular components of the alkali- degraded cornea and blood. Invest. Ophthalmol. Vis. Sci., v. 36, p. 230-237, 1996.

SLATTER, D. Comea and sclera. In: SLATTER, D. (ed.) Fundamentals of Veterinary Ophthalmology 2. ed. Philadelphia: W.D. Saunders CO., 1990. p. 257-303.

TWINING, S. S. et al. Corneal synthesis of a1-Proteinase inhibitor (a1antitrypsin). Invest. Ophthalmol. Vis. Sci. v. 35, p. 458-462, 1994.

WARD, D. A. Part 3. Mydriatics/cicloplegics, anesthetic, tear substitutes and stimulators, intraocular irrigating fluids, disifectants, viscoelastic, fibronolytic agents, tissue adhesives, and anticollagenase agents. In: Gelatt, K.N. (ed.) Veterinary ophthalmology 3. ed. Philadelphia: Lippincott Williams \& Wilkins, 1998. p. 347-348.

WARING, G. O. Corneal structure and pathophysiology. In: Leibowitz, H. (ed.) Corneal disorders: clinical diagnosis and management (ed.). Philadelphia: WB Saunders CO., 1984. p. 3-25.

WAGONER, M. D. Chemical injuries of the eye: current concepts in pathophysiology and therapy. Survey Ophthalmol., v. 41, p. 275-314, 1997.

WHITLEY, R. D.; GILGER, B. C. Diseases of the canine cornea and sclera. In: GELATT, K. N. (Ed.) Veterinary Ophthalmology 3. ed. Philadelphia: Lippincott Williams \& Wilkins, 1998. p. 635-655. 